\title{
Effects of temperature and salinity on spawning of the brackish water bivalve Corbicula japonica in Lake Abashiri, Hokkaido, Japan
}

\author{
Katsuhisa Baba ${ }^{1, *}$, Masahide Tada $^{2}$, Toshifumi Kawajiri ${ }^{3}$, Yasuhiro Kuwahara ${ }^{1}$ \\ ${ }^{1}$ Hokkaido Abashiri Fisheries Experimental Station, 31 Masuura, Abashiri, Hokkaido, Japan \\ ${ }^{2}$ Hokkaido Wakkanai Fisheries Experimental Station 4-5-4, Hourai, Wakkanai, Hokkaido, Japan \\ ${ }^{3}$ Nishiabashiri Fisheries Cooperative Association 330, Yobito, Abashiri, Hokkaido, Japan
}

\begin{abstract}
The abundance of planktonic larvae (veliger) of Corbicula japonica in Lake Abashiri, which is near the northern limit of this species' range, was extremely low in 1995 and 1996, compared to other years $(1989,1990,1994$ and 1997). In histological examinations, the female genital tubules were filled with the atretic oocytes after the spawning season of 1995 . Therefore, it was concluded that most $C$. japonica failed to spawn in 1995. The effects of temperature and salinity on the spawning of $C$. japonica were examined in a spawning induction experiment under laboratory conditions. Probability of spawning by $C$. japonica in the experiment was described by the equation: $1 /\{1+\exp [-(-15.57+0.57 T-12.64 S-0.55 \mathrm{Gam}+0.69 T \cdot S-0.1 T \cdot S \cdot G a m)]\}(T:$ temperature, S: salinity, Gam: dummy variable of 1 or 2, i.e. 1 denotes each group to which the gamete suspension was added and 2 each group to which the gamete suspension was not added). The probability of spawning within the group to which the gamete suspension was added (i.e. Gam =1) explained well both annual and seasonal fluctuations of larval occurrence in Lake Abashiri in past years. The spawning of $C$. japonica may have been extremely low in 1995 and 1996 because of low temperature and low salinity. Such unfavorable conditions for spawning are not exceptional and occurred in 10 out of 21 years for which data were available. In C. japonica, reproduction succeeds less frequently in northern than in southern populations because the probability of spawning depends markedly on the temperature.
\end{abstract}

KEY WORDS: Temperature S Salinity Spawning $\cdot$ Corbicula japonica $\cdot$ Atretic oocyte

\section{INTRODUCTION}

Corbicula spp. are harvested commercially in Japan. The annual catch ranged from 24000 to $27000 \mathrm{t}$ in 1994 to 1996 (Ministry of Agriculture, Forestry and Fisheries 1996-1997), among which Corbicula japonica was the main species. C. japonica is distributed in brackish water lakes and tidal flats of rivers from the south of Japan (about $35^{\circ} \mathrm{N}$ ) to south of Sakhalin (about $50^{\circ} \mathrm{N}$ ) (Kafanov 1991). Lake Abashiri, which is near the northern limit of this species' range, is connected to the Sea of Okhotsk by $7.2 \mathrm{~km}$ of the Abashiri River. Because sea water flows back into the lake, depending on the tide, the lake has a well-oxygenated oligohaline

•E-mail: hf8k-bb@asahi-net.or.jp upper stratum and an anoxic polyhaline lower stratum The habitat of $C$. japonica is restricted to the upper stratum (Nakao 1988).

The maximum water temperature, the salinity of the upper stratum, and the depth of the boundary between water masses in Lake Abashiri differed markedly from year to year (Mikami et al. 1993). The depth of the boundary and the salinity of the upper stratum change mainly according to the amount of precipitation and wind strength (Nakao 1988). When drought conditions continue for several years, the depth of the boundary becomes shallower. Strong winds, which sometimes occur in spring or autumn, cause upwelling of the polyhaline water of the lower stratum. The upwelling of the lower water probably occurs more frequently under conditions with a shallower boundary. Upwelling of the polyhaline water causes the salinity of the upper 
Table 1. Abundance of planktonic larvae during spawning season

\begin{tabular}{|c|c|c|c|c|c|c|c|c|c|}
\hline $\begin{array}{l}\text { Year } \\
\text { (Sampling site) }\end{array}$ & & & & $\begin{array}{r}\text { Larval ab } \\
\text { (S }\end{array}$ & $\begin{array}{l}\text { ndance (n/ } \\
\text { ampling da }\end{array}$ & $\begin{array}{l}2^{3} \pm S D \mid \\
\text { e) }\end{array}$ & & & \\
\hline $\begin{array}{l}1.989 \\
(\operatorname{Stn} 5)\end{array}$ & $\begin{array}{c}0 \\
\text { (14 Jun) }\end{array}$ & $\begin{array}{c}0 \\
(13 \mathrm{Jul})\end{array}$ & $\begin{array}{c}612 \\
(21 \mathrm{JuI})\end{array}$ & $\begin{array}{c}642 \\
(7 \text { Aug) }\end{array}$ & $\begin{array}{c}1217 \\
(21 \mathrm{Aug})\end{array}$ & $\begin{array}{c}698 \\
\text { (31. Aug) }\end{array}$ & $\begin{array}{c}0 \\
(11 \mathrm{Sep})\end{array}$ & & \\
\hline $\begin{array}{l}1990 \\
(\operatorname{Stn} 5)\end{array}$ & $\begin{array}{c}0 \\
(21 \mathrm{Jun})\end{array}$ & $\begin{array}{c}0 \\
(3 \mathrm{Jul})\end{array}$ & $\begin{array}{c}1390 \\
(21 \mathrm{Jul})\end{array}$ & $\begin{array}{c}0 \\
\text { (9 Aug) }\end{array}$ & $\begin{array}{c}1820 \\
(24 \text { Aug) }\end{array}$ & $\begin{array}{c}1656 \\
(6 \mathrm{Sep})\end{array}$ & $\begin{array}{c}0 \\
(23 \text { Sep })\end{array}$ & & \\
\hline $\begin{array}{l}1994 \\
(\operatorname{Stn} 2)\end{array}$ & $\begin{array}{c}91 \\
(1 \mathrm{Aug})\end{array}$ & $\begin{array}{c}5832 \\
\text { (19 Aug) }\end{array}$ & $\begin{array}{c}17694 \\
\text { (30 Aug) }\end{array}$ & & & & & & \\
\hline $\begin{array}{l}1995 \\
\text { (Stns 2, 4) }\end{array}$ & $\begin{array}{c}0 \\
(23 \mathrm{Jul})\end{array}$ & $\begin{array}{l}15 \pm 15 \\
(3 \text { Aug) }\end{array}$ & $\begin{array}{c}2 \pm 2 \\
(22 \text { Aug) }\end{array}$ & $\begin{array}{c}0 \\
\text { (6 Sep) }\end{array}$ & $\begin{array}{c}0 \\
(16 \mathrm{Sep})\end{array}$ & & & & \\
\hline $\begin{array}{l}1996 \\
\text { (Stns 2, 4, 5) }\end{array}$ & $\begin{array}{c}0 \\
(12 \mathrm{Jul})\end{array}$ & $\begin{array}{c}0 \\
\text { (8 Aug) }\end{array}$ & $\begin{array}{c}0 \\
\text { (12 Aug) }\end{array}$ & $\begin{array}{c}7 \pm 2 \\
(20 \text { Aug) }\end{array}$ & $\begin{array}{c}0 \\
(27 \mathrm{Aug})\end{array}$ & & & & \\
\hline $\begin{array}{l}1997^{d} \\
\text { (Stns 1, 2, 3) }\end{array}$ & $\begin{array}{c}0 \\
(15 \mathrm{Jul})\end{array}$ & $\begin{array}{l}26 \pm 21 \\
\{25 \mathrm{Jul}\}\end{array}$ & $\begin{array}{l}479 \pm 47 \\
(1 \mathrm{Aug})\end{array}$ & $\begin{array}{c}603 \pm 655 \\
(13 \mathrm{Aug})\end{array}$ & $\begin{array}{c}3 \pm 2 \\
(19 \text { Aug })\end{array}$ & $\begin{array}{c}74 \pm 46 \\
(29 \mathrm{Aug})\end{array}$ & $\begin{array}{c}141 \pm 75 \\
(9 \mathrm{Sep})\end{array}$ & $\begin{array}{l}95 \pm 40 \\
(16 \mathrm{Sep})\end{array}$ & $\begin{array}{c}0 \\
(3 \text { Oct })\end{array}$ \\
\hline
\end{tabular}

stratum to increase and forces the boundary between the water masses deeper (Abashiri Local Office of Hokkaido Development Bureau unpubl. data).

Maru (1981) reported the spawning season of Corbicula japonica to be July to September. However, our recent work revealed that recruitment of $C$. japonica was extremely low in 1995 (Baba \& Takahashi 1997). To clarify the cause of such low recruitment, we examined the relationships between temperature, salinity and spawning by means of an experiment performed under laboratory conditions, and verified the relationships with field data. This report is very important for resource management because it is the first to elucidate the environmental conditions necessary for the spawning of $C$. japonica.

\section{MATERIALS AND METHODS}

Occurrence of planktonic larvae during spawning season. Samplings of planktonic larvae (veliger) were carried out 3 to 9 times during the spawning seasons of 1989 to 1990 and 1994 to 1.997 at 1 to 3 sites. In 1997. there were duplicate samples at each site. Sampling locations and dates are shown in Fig. 1 and Table 1. Larvae were collected by a plankton net hauled vertically from the depth of the boundary between the upper and the lower strata (depth from 5 to $7 \mathrm{~m}$ ) to the surface. A $300 \mathrm{~mm}$ diameter plankton net of NXX-13 (mesh: $95 \times 95 \mu \mathrm{m}$ ) was used. The numbers of planktonic larvae were counted after the samples had been fixed with $3 \%$ neutralized formalin.

Environmental data. Temperatures and salinities at the water surface during the spawning season (July to September) were obtained for Lake Abashiri from unpublished data of Abashiri Local Office of Hokkaido Development Bureau from 1994 to 1997 . The data were collected once or twice a week.

Additional data on monthly water surface temperatures and salinities (1977 to 1993), as well as annual maximum temperatures, were obtained from 'Results of Water Quality Analysis in Public Waters' (Hokkaido Government 1979-1995). Collection locations for environmental data are shown in Fig. 1.

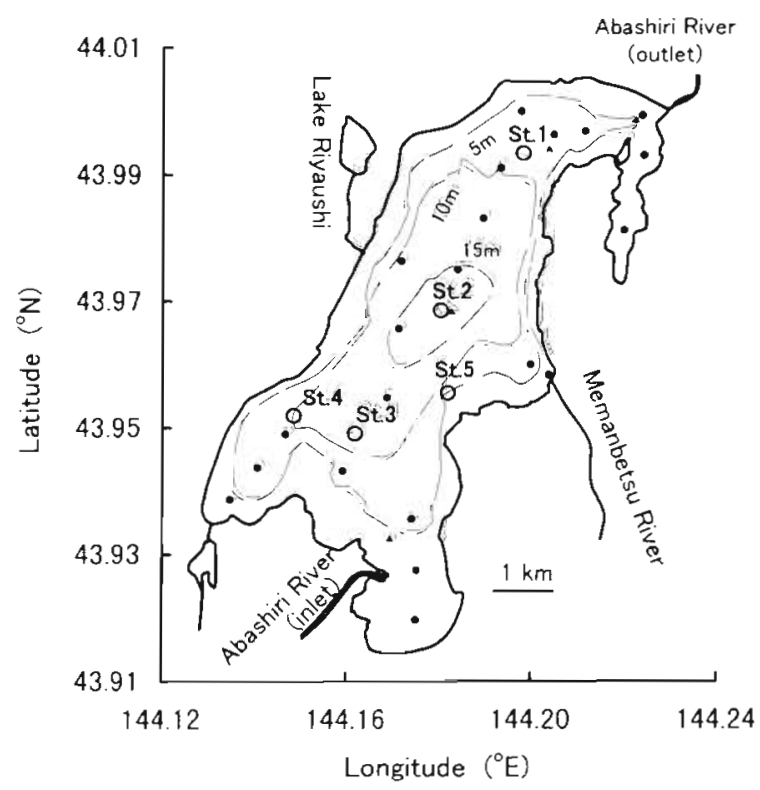

Fig. 1. Location of sampling sites in Lake Abashiri. Planktonic larvae of Corbicula japonica from different stations each year as follows: 1989, 1990 (Stn 5), 1994 (Stn 2), 1995 (Stns 2 and 4), 1996 (Stns 2, 4 and 5), 1997 (Stns 1, 2 and 3). Measurements of temperature and salinity were taken at (4) 4 sites from 1977 to 1993 and (•) 21 sites from 1994 to 1997 
Histological examination. A histological examination was performed on the gonads of 10 to 20 individuals (20 to $30 \mathrm{~mm}$ shell length) sampled monthly in 1995 and 1997. Tissues were fixed in Bouin's solution and dehydrated through a graded alcohol series, embedded in Histprep 568 (Wako Pure Chemical Industries, Ltd.) and sliced in thicknesses of $7 \mu \mathrm{m}$. The sections were stained with Mayer's hematoxylin-eosin double stain for examination under a light microscope.

Spawning induction experiment. The experiment on induction of spawning was carried out from 31 August to 6 September 1996. In 1996, few planktonic larvae were observed in Lake Abashiri. Twenty individuals were incubated in $10 \mathrm{l}$ circular containers with $6 \mathrm{l}$ of salinity-adjusted water. Salinity was adjusted to 0.0 (tap water only), 1.2, 2.3, 3.4, and 4.5 psu (practical salinity units) with seawater and tap water. Salinity was measured by an inductivity coupled salinometer (Model $601 \mathrm{Mk} 1 \mathrm{~V}$, YEO-KAL Environmental Electronics, Sydney, Australia). The containers were kept in incubators, with temperatures adjusted to $21.5,22.5$, $23.5,24.5$ and $26.0^{\circ} \mathrm{C}$.

In half the groups spawning was stimulated by adding $50 \mathrm{ml}$ of gamete suspension from incubation water of groups previously spawned at 4.5 psu and $26^{\circ} \mathrm{C}$. Success or failure of spawning induction was determined after $36 \mathrm{~h}$ of incubation. The success or failure was easily distinguished because the incubation water became turbid with the gametes released by spawning groups. In the dilution procedure, not only salinity but also food, nutrients or other substances might be changed in incubation water. We thought these changes would not affect the results because of the short duration of the experiments.

The results of the experiment were analyzed by logistic regression calculated by the maximum-likelihood method. Logistic regression is useful for analysis of binary data (Sokal \& Rohlf 1995). The result of spawning induction was used as a binary dependent variable (i.e. a value of 1 was assigned to each group in which spawning was induced and a value of 0 to a group without spawning). Temperature and salinity were used as continuous independent variables. Addition or exclusion of a gamete suspension was used as a categorical independent variable (i.e. a dummy variable of [1] was assigned to each group to which the gamete suspension was added and [2] was assigned to each group to which the gamete suspension was not added). A dummy variable is usually used in the logistic regression when a categorical variable is treated as an independent variable (Tango et al. 1996)

Two steps were applied to select independent variables for the logistic analysis. In the first, the main effects, i.e. temperature $(T)$, salinity $(S)$, adding gamete suspension (Gam), and their combinations were used as independent variables ( 7 cases). The best combination of the main effects was selected by the Akaike Information Criterion (AIC). In the second, the interaction terms, i.e. $T \times S, S \times$ Gam, $T \times G a m, T \times S \times$ Gam, and their combinations were added to the best combination of main effects ( 15 cases). The best model using both the main effects and the interaction terms was selected by the AIC. The AIC was calculated as: AIC $=-2 \times \ln ($ maximum-likelihood $)+2(N)$, where $N=$ the number of regression coefficients in the model. The AIC is useful for simultaneously comparing models with consideration for both maximum-likelihood and number of parameters (Akaike 1973, Sakamoto et al. 1983). The equation of the logistic regression used in this study was:

$$
\begin{aligned}
& f(T, S, \text { Gam })=1 /\{1+\exp [-g(T, S, \text { Gam })]\} \\
& \text { where } \\
& g(T, S, \mathrm{Gam})=a_{0}+a_{1} T+a_{2} S+a_{3} \mathrm{Gam}+a_{4} T \cdot S \\
& +a_{5} S \cdot \mathrm{Gam}+a_{6} T \cdot \mathrm{Gam}+a_{7} T \cdot S \cdot \mathrm{Gam}
\end{aligned}
$$

and $a_{i}(i=0$ to 7$)$ are the regression coefficients, which are not simultaneously zero. $f(T, S, \mathrm{Gam})$ represents the probability of spawning in Corbicula japonica. $g(T, S, G a m)$ is a linear component of the regression equation representing a log-odds ratio between the probabilities of a positive response and no response to spawning induction.

Salinity and larval development. Fertilized eggs obtained by the spawning induction experiment were incubated in water of the same salinity (i.e. 1.2, 2.3, 3.4, or $4.5 \mathrm{psu}$ ) at room temperature $\left(21\right.$ to $23^{\circ} \mathrm{C}$ ) for $24 \mathrm{~h}$ to determine whether the eggs could develop to the $D$ shaped veliger at each salinity. Twenty-four hours after spawning, the number of D-shaped veligers among about 300 swimming larvae at each salinity was counted. Results were analyzed by logistic regression with the maximum-likelihood method. The logistic regression is useful for analysis of ratio data (Sokal \& Rohlf 1995). We did not feed the larvae during the experiment.

\section{RESULTS}

Occurrence of planktonic larvae in each year are shown in Table 1. Numbers in 1995 and 1996 were extremely low compared with the other years (1989, 1990, 1994 and 1997).

Histological changes in female and male gonads during the spawning season in 1995 and 1997 are shown in Fig. 2. The female genital tubules were filled with mature oocytes at the beginning of the spawning season in both 1995 and 1997 (Fig. 2A, C). After the spawning season in 1995, female genital tubules were filled with atretic oocytes (Fig. 2B), but in 1997, it was observed that the genital tubules were either vacant or 

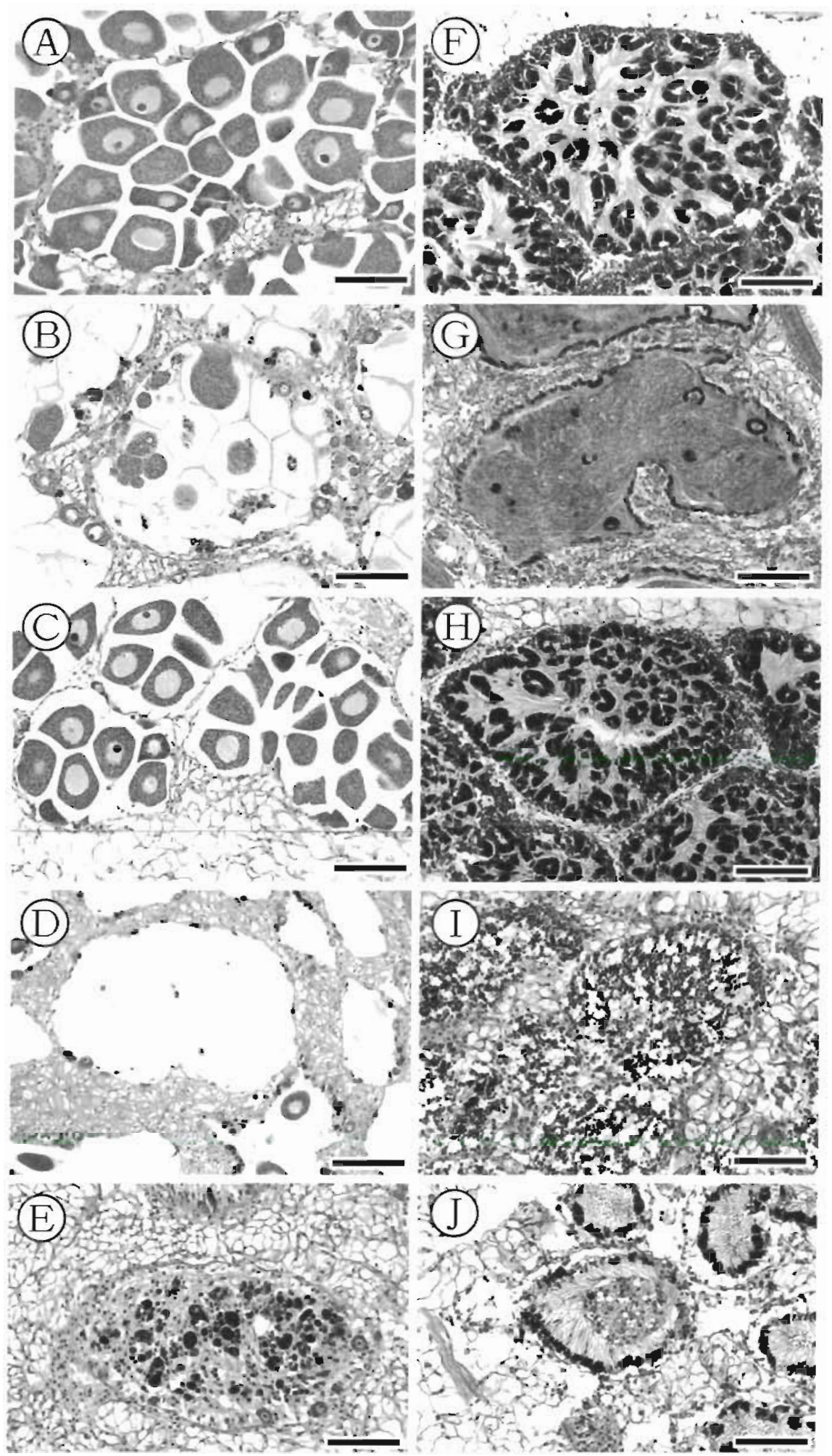

Fig. 2. Corbicula japonica. Histological changes in gonads in 1995 and 1997 (A to $\mathrm{E}$ : female, $\mathrm{F}$ to $\mathrm{J}$ : male). (A) Female gonad at the beginning of spawning season (3 August 1995) showing genital tubules filled with mature oocytes. (B) Female gonad after the spawning season. (13 October 1995) showing genital tubules filled with atretic oocytes. (C) Female gonad at the beginning of the spawning season (1 August 1997) showing genital tubules filled with mature oocytes. (D, E) Female gonad after spawning season in 1997 (24 October) showing empty genital tubules (D), and some oocytes degenerated by phagocytosis (E). (F) Male gonad at the beginning of the spawning season in 1995 (3 August) showing genital tubules filled with mature sperm. (G) Male gonad after the spawning season in 1995 (13 October) showing genital tubules filled with many degenerating sperm. (H) Male gonad at the beginning of the spawning season in 1997 (1 August) showing genital tubules filled with mature sperms. (I, J) Male gonad after the spawning season in 1997 (24 October) showing few sperm remaining in the genital tubules (I), or some degenerated sperm (J). Bars $=100 \mu \mathrm{m}$ contained some oocytes degenerated by phagocytosis (Fig. 2D, E). Tubules filled with the atretic oocytes were observed in all the females examined in 1995, but none in 1997 The charactenstics of the atretic oocytes of
Corbicula japonıca observed in 1995 were similar to those of the atretic oocytes described by Beninger \& Pennec (1991) in Pecten maximus: the nucleus lost its basophilic properties, the cytoplasm became clear, the 
Table 2. Corbicula japonica. Results of spawning induction experiments. Values are number of spawning-induced groups/ number of experimental groups

\begin{tabular}{|c|c|c|c|c|c|c|c|c|c|c|c|}
\hline \multirow{3}{*}{$\begin{array}{l}\text { Salinity } \\
\text { (psu) }\end{array}$} & \multicolumn{5}{|c|}{ Gamete suspension added - } & 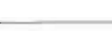 & \multicolumn{5}{|c|}{ Gamete suspension not added } \\
\hline & \multicolumn{5}{|c|}{ Temperature $\left({ }^{\circ} \mathrm{C}\right)$} & \multirow{2}{*}{$\begin{array}{c}\text { Salinity } \\
\text { (psu) }\end{array}$} & \multicolumn{5}{|c|}{ Temperature $\left({ }^{\circ} \mathrm{C}\right)$} \\
\hline & 21.5 & 22.5 & 23.5 & 24.5 & 26.0 & & 21.5 & 22.5 & 23.5 & 24.5 & 26.0 \\
\hline 4.5 & $0 / 1$ & $1 / 2$ & $2 / 2$ & $1 / 1$ & $2 / 2$ & 4.5 & $0 / 1$ & $0 / 2$ & $0 / 2$ & $0 / 1$ & $0 / 2$ \\
\hline 3.4 & $0 / 1$ & $1 / 2$ & $1 / 2$ & $1 / 1$ & $2 / 2$ & 3.4 & $0 / 1$ & $0 / 2$ & $0 / 2$ & $0 / 1$ & $2 / 2$ \\
\hline 2.3 & $0 / 1$ & $0 / 2$ & $2 / 2$ & $1 / 1$ & $2 / 2$ & 2.3 & $0 / 1$ & $0 / 2$ & $0 / 2$ & $1 / 1$ & $2 / 2$ \\
\hline 1.2 & $0 / 1$ & $0 / 2$ & $1 / 2$ & $1 / 1$ & $2 / 2$ & 1.2 & $0 / 1$ & $0 / 2$ & $0 / 2$ & $1 / 1$ & $0 / 2$ \\
\hline 0.0 & $0 / 1$ & $0 / 2$ & $0 / 2$ & $0 / 1$ & $0 / 2$ & 0.0 & $0 / 1$ & $0 / 2$ & $0 / 2$ & $0 / 1$ & $0 / 2$ \\
\hline
\end{tabular}

Table 3. Corbicula japonica. Logistic regression results from spawning induction experiment. Only the best models using the same number of independent variables are shown. $T$ : temperature $\left({ }^{\circ} \mathrm{C}\right), S$ : salinity (psu), Gam: adding gamete suspension (dummy variable 1 or 2 )

\begin{tabular}{|c|c|c|c|c|c|c|c|c|c|c|c|}
\hline \multirow{2}{*}{$\begin{array}{l}\text { Model } \\
\text { no. }\end{array}$} & \multirow{2}{*}{$\begin{array}{l}\text { Used independent } \\
\text { variable }\end{array}$} & \multicolumn{8}{|c|}{ Regression coefficient } & \multirow[t]{2}{*}{ AIC } & \multirow[t]{2}{*}{$\mathrm{p}$} \\
\hline & & $a_{0}$ & $a_{1}$ & $a_{2}$ & $a_{3}$ & $a_{4}$ & $a_{5}$ & $a_{6}$ & $a_{7}$ & & \\
\hline \multicolumn{12}{|c|}{ Main effect only } \\
\hline 1 & $T$ & -18.65 & 0.75 & & & & & & & 85.8 & $1.2 \times 10^{-5}$ \\
\hline 2 & T, Gam & -25.84 & 0.98 & & 2.54 & & & & & 71.8 & $2.4 \times 10^{-8}$ \\
\hline 3 & $T, S$, Gam & -32.46 & 1.17 & 0.71 & 3.02 & & & & & 63.7 & $8.4 \times 10^{-10}$ \\
\hline \multicolumn{12}{|c|}{ Main effect plus interaction term } \\
\hline 4 & $T, S$, Gam, $S \times$ Gam & -35.12 & 1.34 & 2.29 & 0.62 & & & -1.08 & & 60.8 & $3.4 \times 10^{-10}$ \\
\hline 5 & $T, S$, Gam, $T \times S, T \times S \times$ Gam & -15.57 & 0.57 & -12.64 & -0.55 & 0.69 & & & -0.10 & 56.3 & $6.1 \times 10^{-11}$ \\
\hline 6 & $\begin{array}{l}T, S, G a m, T \times S, S \times \text { Gam } \\
T \times S \times \text { Gam }\end{array}$ & -18.03 & 0.66 & -25.32 & -0.53 & 1.22 & & 9.33 & -0.48 & 57.1 & $1.2 \times 10^{-10}$ \\
\hline 7 & $\begin{array}{l}T, S, \text { Gam, } T \times S, T \times \text { Gam } \\
S \times \text { Gam, } T \times S \times \text { Gam }\end{array}$ & -14.66 & 1.03 & -23.83 & -6.76 & 1.16 & -0.25 & 8.12 & -0.43 & 59.0 & $3.9 \times 10^{-10}$ \\
\hline
\end{tabular}

oocytes appeared terminally empty, and finally the cell membranes ruptured.

The male genital tubules were filled with mature sperm at the beginning of the spawning season in both 1995 and 1997 (Fig. 2F, H). After the spawning season in 1995, the genital tubules were filled with intensively degenerating sperm cells (Fig. 2G), whilst in 1997 small degenerating cells were observed and few sperm remained (Fig. 2I, J).

The histological changes in 1997 corresponded with. a previous report of Maru (1981), which showed details of the histological changes in gonads of Corbicula japonica.

Results of the spawning induction experiment are shown in Table 2. Spawning or sperm release was observed in most individuals of the spawned groups. The results of logistic regression are shown in Table 3 , where only the best models for each set using the same number of independent variables are indicated as representative examples. Model-5, which used the 3 main effects ( $T, S, G a m)$ and the 2 interaction terms $(T \times S$ and $T \times S \times \mathrm{Gam}$ ), was the best in terms of AIC. Model5 and model- 6 were not significantly different in terms of AIC, but we selected model-5 as the best, because it showed the lowest AIC and used a lower number of independent variables. In the AIC, a difference of 1 or more is regarded as statistically significant (Sakamoto et al. 1983). Model-5 was used to calculate the probability surfaces in Fig. 3.

Occurrence of planktonic larvae, temperature and salinity during the spawning season and the spawning probability calculated by model-5 with the dummy variable Gam = 1 in 1994, 1995, 1996 and 1997 are shown in Fig. 4. We did not have such intensive environmental data for 1989 and 1990 so we excluded these years.

The spawning probability function was useful in explaining the timing of the larval occurrences. Some delay was observed from a peak in the spawning probability to a peak of larval occurrence in 1995, 1996 and 1997. Very high density of planktonic larvae was observed at the end of August 1994. This high density corresponds to increased salinity from about 2.2 to 2.5 psu. The spawning halted in mid August 1997 due to decreased temperature and resumed at the end of August when temperature increased. 


\section{Group to which gamete suspension was not added}

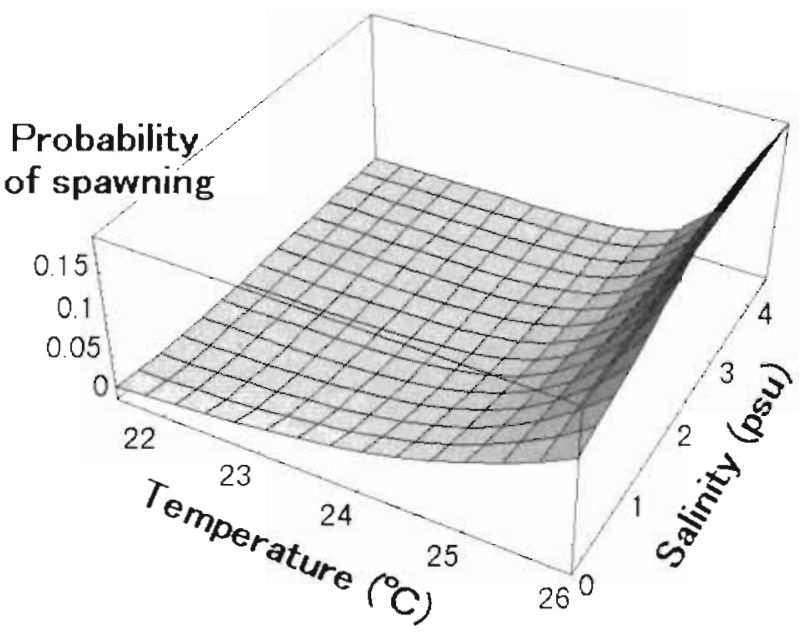

\section{Group to which gamete suspension was added}

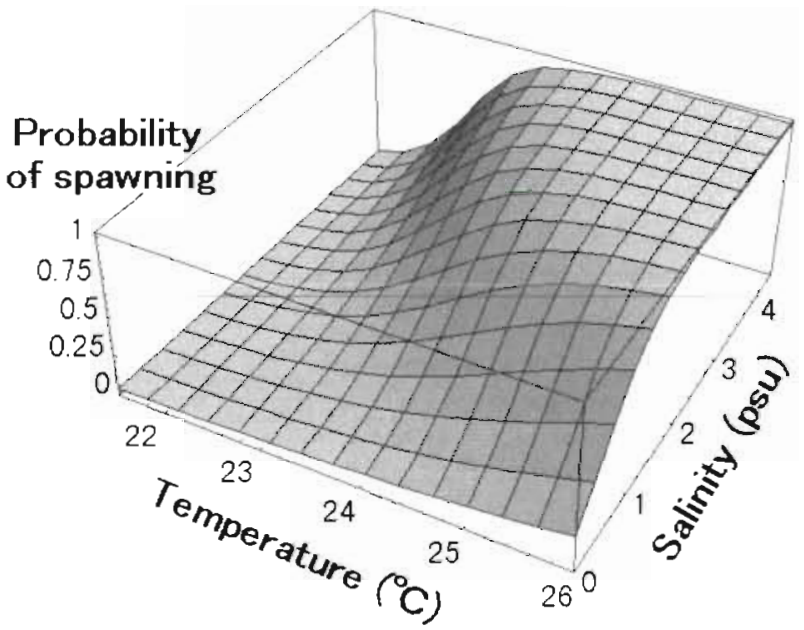

Fig. 3. Corbicula japonica. Relationship between spawning probability, temperature and salinity predicted by model-5 in Table 3. Upper panel shows the relationship between spawning probability, temperature and salinity of the groups to which the gamete suspension was not added (i.e. the dummy variable Gam = 2 in model-5). Lower panel shows the relationship of groups to which the gamete: suspension was added (i.e. the dummy variable Gam $=1$ in model-5)

We suggest that the magnitude of spawning was low in 1995 and 1996 because of low temperatures and low salinity in the upper stratum of the water column.

There is the potential that some of the interannual variation might be attributed to differences in sampling sites from year to year. In 1994, large numbers of planktonic larvae were observed in the central portion of Lake Abashiri, even though the habitat of Corbicula japonica is restricted to the margins. In 1995, 1996 and 1997, sampling was more intensive than in 1994. How- ever, we found few planktonic larvae in 1995 and 1996 In 1997, there were fewer planktonic larvae than in 1994. Consequently, we believe our observations actually reflected the magnitude of population spawning in each year. Furthermore, larval abundance seemed to be associated more with changes in the temperature and the salinity than the sampling location (Fig. 4).

The isopleths of the spawning probability $(0.1,0.25$, $0.5,0.75,0.9)$ calculated by model-5 with the dummy variable Gam $=1$, the larval occurrences in Lake Abashiri, and the temperature and salinity (mean \pm $\mathrm{SD}$ ) of the surface of the upper stratum at the maximum temperature in the lake in past years are compared in Fig. 5. The maximum water temperature and the salinity in the upper stratum of the lake differ markedly from year to year. Maximum water temperatures ranged from 19 to $22^{\circ} \mathrm{C}$ in cold summer years and from 26 to $28^{\circ} \mathrm{C}$ in warm summer years. Salinity at the maximum temperature ranged from 6.5 to 0 psu.

The isopleths can be regarded as an environmental border range for the spawning of Corbicula japonica, because they explained the larval occurrences of past years. Unfavorable conditions for spawning are not exceptional and occurred in 10 out of 21 years for which data were available

Twenty-four hours after spawning, the mean percentages $\pm 95 \%$ confidence intervals of the D-shaped veliger at each salinity are shown with the probability estimated from the logistic regression in Fig. 6. The equation for the logistic regression was $f(x)=1 / 11+$ $\exp [-(-6.42+2.37 x)]\}$, where $x$ is salinity $(p<0.01)$. The salinity at probability 0.5 of the logistic regression was 2.7 psu. At 2.3 psu, $72.2 \%$ of the swimming larvae did not reach the $\mathrm{D}$-shaped veliger stage within $24 \mathrm{~h}$, and some were abnormal (swollen). Not only might their development have been delayed, but also some damage may have occurred at 2.3 psu. At 1.2 psu, most fertilized eggs developed to the morula stage $12 \mathrm{~h}$ after spawning and many abnormal (swollen) blastulae were observed after $24 \mathrm{~h}$. No D-shaped veliger stage was observed at 1.2 psu.

\section{DISCUSSION}

Temperature and salinity appear to regulate spawning in Corbicula japonica (Table 3, Fig. 3). More spawning occurs when environmental conditions exceed the border range (isopleths of spawning probability from 0.1 to 0.9 ), especially when favorable conditions persist (Figs. 4 \& 5). Much less spawning occurs when conditions do not exceed the border range (Figs. 4 \& 5).

In years unfavorable for spawning, intensive oocyte atresia occurs in mature gonads of individuals after the 
Larval abundance and spawning probability

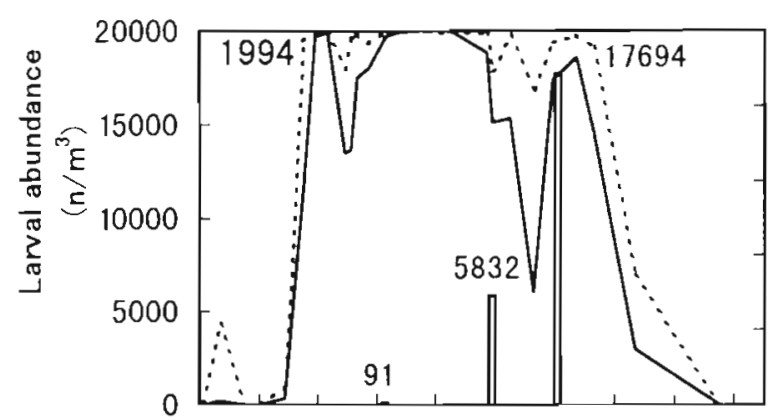

Temperature $\left({ }^{\circ} \mathrm{C}\right)$
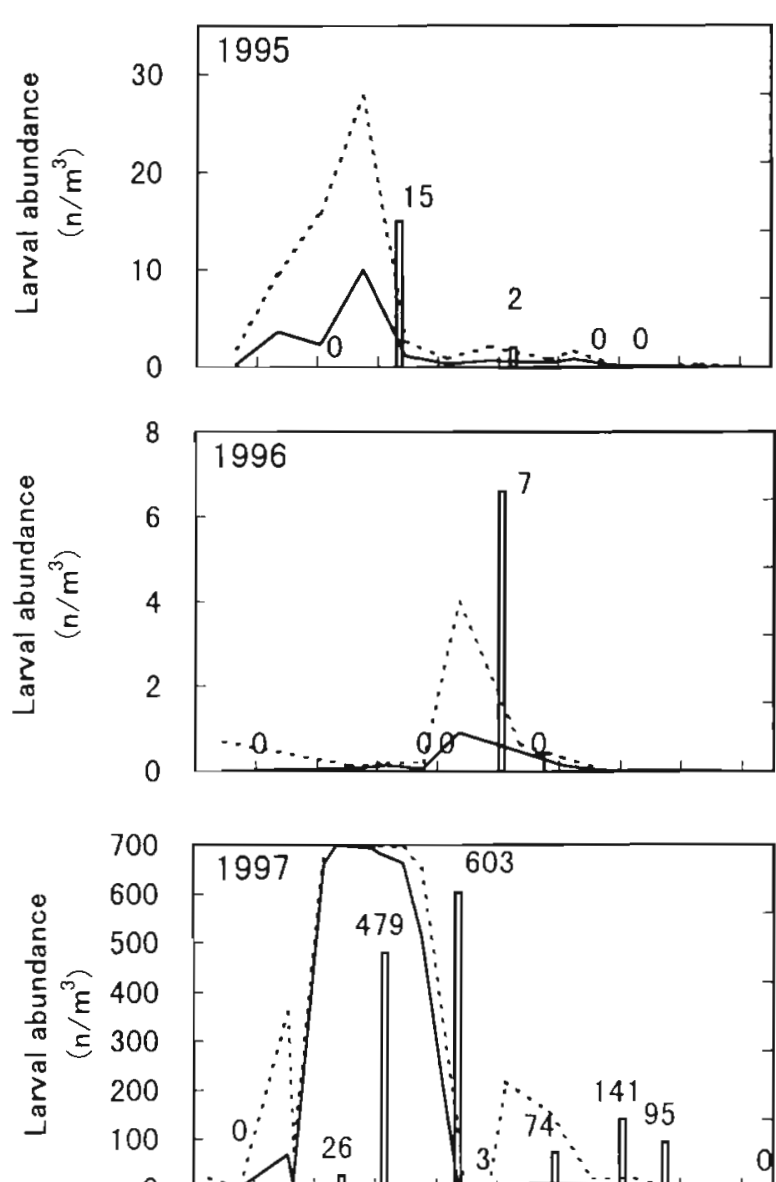

0
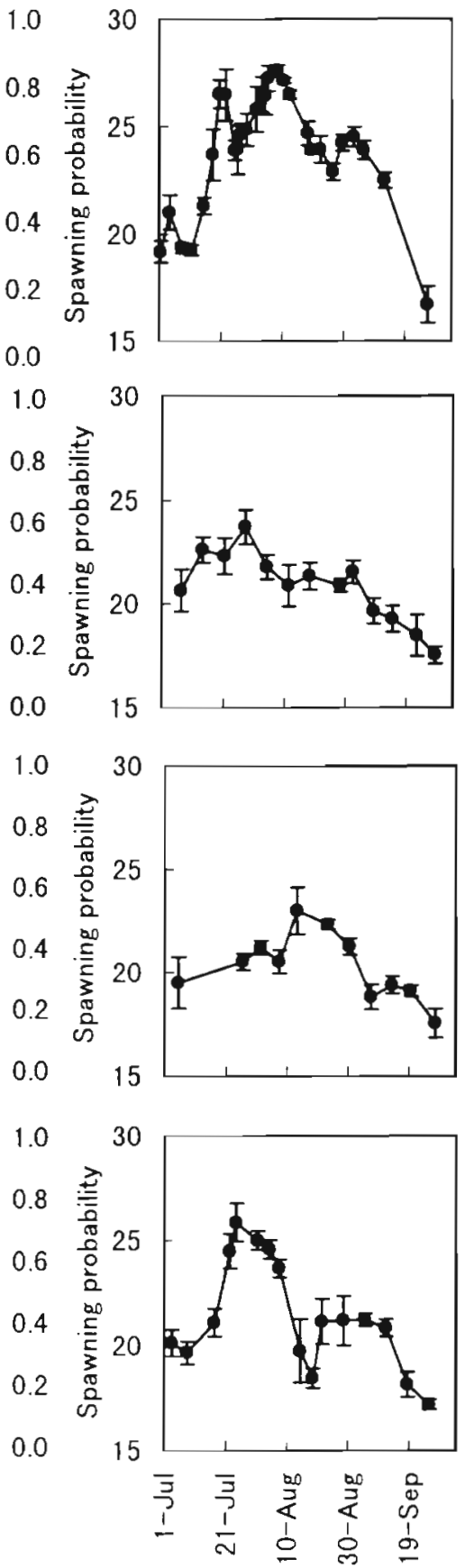

Salinity (psu)
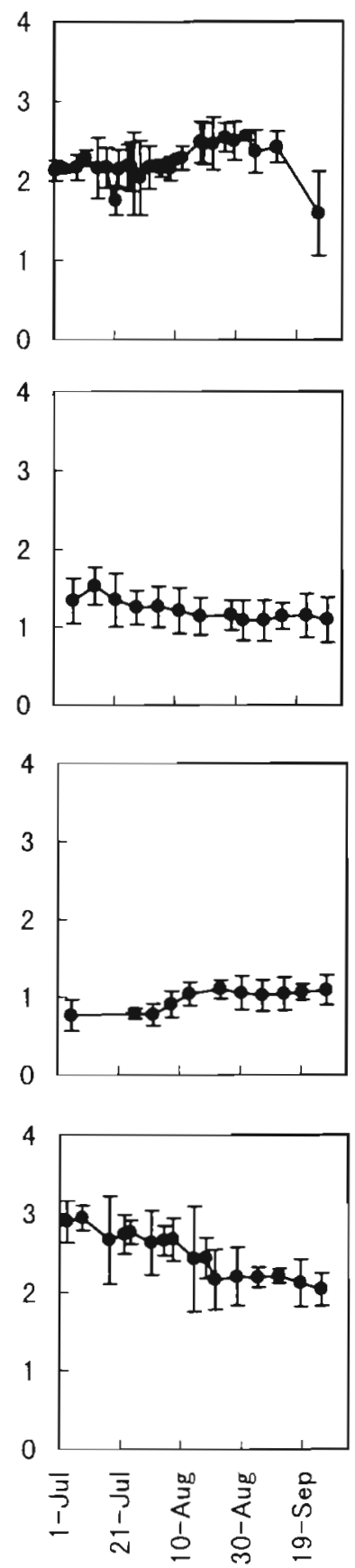

Fig. 4. Temperature and salinity changes (mean $\pm \mathrm{SD}$ ), larval abundance (bars), and spawning probabilities (solid and dashed lines) calculated from model-5 with dummy variable Gam = 1, during spawning season from 1994 to 1997 . (—) Spawning probability calculated from average temperature and salinity. (- - - Maximum probability on each day

spawning season. This is the first report of such intensive oocyte atresia in Corbicula japonica. Oocyte atresia is also regulated by environmental conditions in other marine bivalves such as Pecten maximus, in which the borderline water temperature is 15.5 to $16.0^{\circ} \mathrm{C}$ (Paulet et al, 1988, Beninger \& Pennec 1991).
We observed oocytes degenerated by phagocytosis after the spawning season in 1997. Degeneration of oocytes by phagocytosis was also reported by Maru (1981).

As shown in Fig. 4, there was some delay between a peak in the predicted spawning probability and a peak 


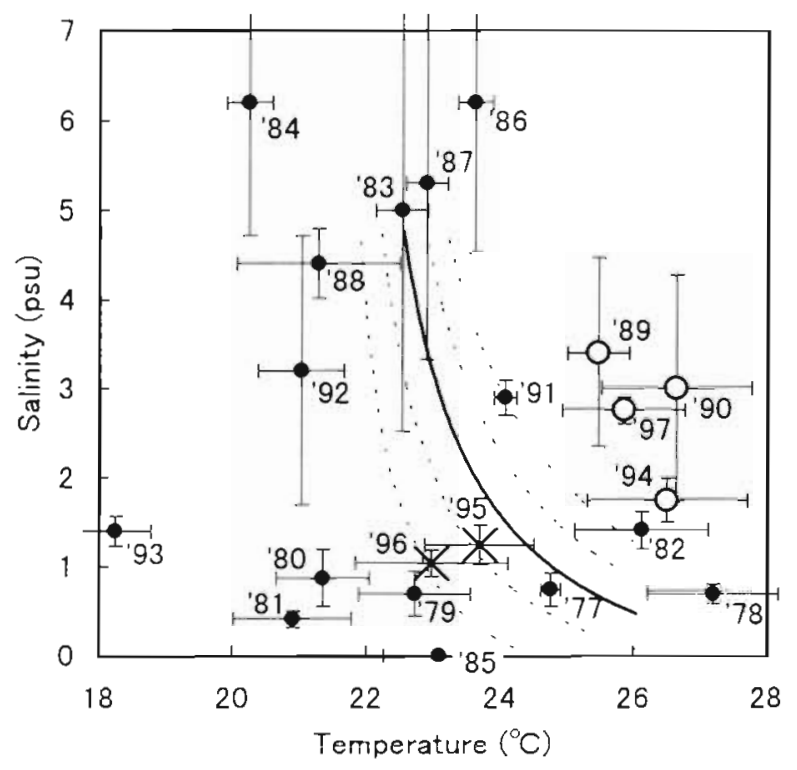

Fig. 5. Isopleths of spawning probability calculated from model-5 with the dummy variable Gam $=1$. Larval occurrence: $(O)$ abundant, $(X)$ few, $(-)$ no data, and maximum surface temperature and salinity (mean $\pm \mathrm{SD}$ ) of Lake Abashiri in past years. (-) Probability 0.5, ( - ) probabilities 0.9, $0.75,0.25,0.1$ from upper right to lower left, respectively. Numbers indicate years

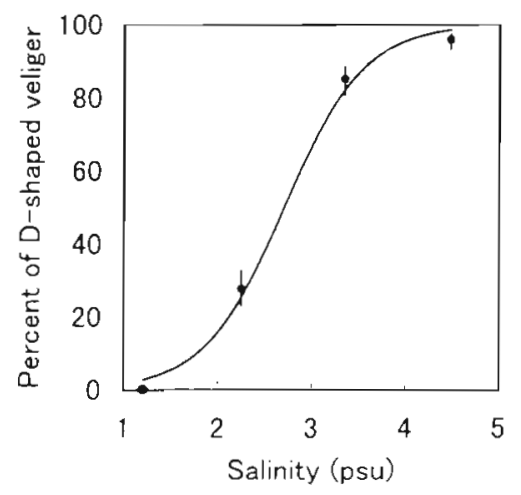

Fig. 6. Corbicula japonica. Mean percentages $\pm 95 \%$ confidence intervals of $\mathrm{D}$-shaped veliger $24 \mathrm{~h}$ after spawning at each salinity and probability of the logistic regression

in larval abundance in 1995, 1996 and 1997. It takes about $1 \mathrm{~d}$ to reach the veliger stage after fertilization, and the planktonic phase is about 6 to $10 \mathrm{~d}$ in Corbicula japonica (Tanaka 1984). The time required to pass through these phases may cause the observed delay.

In 1997, spawning seemed to cease in mid August when temperature declined, but then resumed when temperature increased. The magnitude of the second spawning event was greater than one might have expected from the spawning probability estimate (Fig. 4). Model-5 with the dummy variable Gam = 1 explained the timing of larval occurrences during the spawning season, but not the precise magnitude of the events. Perhaps time series models that include cumulative effects of environmental variables would be more useful in predicting the abundance of larva.e.

In Corbicula fluminea, a freshwater ovoviviparous hermaphroditic species, release of juveniles begins when temperature rises above 18 to $19^{\circ} \mathrm{C}$, but declines when temperatures rise above $26^{\circ} \mathrm{C}$ (McMahon 1983). In C. japonica, a brackish-water oviparous dioecious species, spawning began at temperatures above $22^{\circ} \mathrm{C}$, and inhibition of spawning by high temperature was not observed (Figs. 3 \& 4). This suggests C. japonica may be more adapted to high temperatures than $C$. fluminea.

In the spawning induction experiment, some groups spawned at salinities of 1.2 or 2.3 psu (Table 2, Fig. 3), but these salinities were insufficient for larval development (Fig. 6). Asahina (1941) reported that the development of the embryo could proceed at salinities from 3 to 28 psu in Corbicula japonica, and Sasaki (1981) reported that the range was from 0.6 to 6.1 psu. Neither study determined whether the embryo could reach the veliger stage. In our experiment, the salinity that guaranteed embryonic and larval development to the D-shaped veliger stage was $3.1 \mathrm{psu}$, and the value at which half of the swimming larvae reached the veliger stage was 2.7 psu (Fig. 6). Under natural conditions, many planktonic larvae were observed in 1994 in the low-salinity upper stratum of Lake Abashiri (Figs. $4 \& 5$ ). A large portion of the planktonic larvae were found near the boundary between the oligohaline upper stratum and the polyhaline lower stratum in 1997 (authors' unpubl. data). These observations suggest that larvae of $C$. japonica may be capable of salinity-related movement. A salinity-related response at the larval stage has also been reported in the marine bivalve Mercenaria mercenaria (Sastry 1979).

A substantial increase in abundance of planktonic larvae occurred between 1 August and 19 August 1994 and corresponded to an increase in salinity from 2.2 to 2.5 psu. Although this salinity change may seem small, it occurred within a range at which there was a steep slope in the relationship between salinity and percentage of $D$-shaped veliger $24 \mathrm{~h}$ after spawning (Fig. 6), suggesting that small changes within this salinity range could have important effects on larval survival and development.

Unfavorable environmental conditions for spawning are not exceptional, and in fact were observed in about half the years studied (Fig. 5). Reproduction appears to succeed less frequently in northern than in southern populations of Corbicula japonica, because the necessary environmental conditions for spawning depend heavily on temperature. 
Acknowledgements. We express our thanks to Mr H. Yabe, Vice-Head of the River Improvement Section in the Abashiri Local Office of the Hokkaido Development Bureau, for providing environmental data on Lake Abashiri.

\section{LITERATURE CITED}

Akaike $H$ (1973) Information theory and an extension of the maximum likelihood principle. In: Petrov BN. Csaki F (eds) 2nd lnt Symp on Information Theory. Akademiai Kiado, Budapest, p 267-281

Asahina E (1941) An ecological study of Corbicula japonica group, the brackish water bivalve, with special reference to the environmental factors of its habitat in Hokkaido. Bull Jpn Soc Sci Fish 10:143-152 (in Japanese)

Baba K, Takahashi K (1997) Experiment of seed collection of Corbicula japonica. Annu Rep of 1995 Fiscal Year. Hokkaido Abashiri Fisheries Experimental Station, Hokkaido, p 227-229 (in Japanese)

Beninger PG. Pennec ML (1991) Functional anatomy of scallops. In: Shumway SE (ed) Scallops: biology, ecology and aquaculture. Elsevier Science Publishers BV, Amsterdam, p $133-223$

Hokkaido Government (1979-1995) Results of water quality analysis in public waters. Hokkaido Government, Sapporo (in Japanese)

Kafanov AI (1991) Bivaives on continental shelf and continental slope of Northern Pacific. Redaktsionno-izdatelskii otdel DVO AN SSSR, Vladivostok, p 81-82

Maru K (1981) Reproductive cycle of the brackish-water

Editorial responsibility: Otto Kinne (Editor),

Oldendorf/Luhe, Germany bivalve, Corbicula japonica, in Lake Abashiri. Sci Rep Hokkaido Fish Exp Stn 23:83-95 (in Japanese)

McMahon RF (1983) Ecology of an invasive pest bivalve, Corbicula. In: Russell-Hunter WD (ed) The Mollusca (Vol 6. Ecology). Academic Press, Orlando, FL, p 505-561

Mikami H. Hino S, Arisue J (1993) Variation in chemical and biological environment with blue-tide (Aoshio) in Lake Abashiri. RHIES (Rep Hokkaido Inst Environ Sci) 20: 55-60 (in Japanese)

Ministry of Agriculture, Forestry and Fisheries (1996-1997) Statistics on fisheries and water culture production. Tokyo (in Japanese)

Nakao K (1988) Fundamental rules on the environmental change in Lake Abashiri. Jpn J Limnol 49:293-301

Paulet YM, Lucas A, Gerard A (1988) Reproduction and larval development in two Pecten maximus (L.) populations from Brittany. J Exp Mar Biol Ecol 119:145-156

Sakamoto Y, Ishiguro M, Kitagawa G (1983) Information statistics (Jouhouryou Toukei Gaku). Kyouritu Shuppan, Tokyo (in Japanese)

Sasaki M (1981) Spawning induction of Corbicula japonica. Rep Freshwater Fish Exp Stn Ibaraki Prefecture 18:65-70

Sastry AN (1979) Pelecypoda (excluding Ostreidae). In: Giese AC, Pearse JS (eds) Reproduction of marine invertebrates. Academic Press, New York, p 113-292

Sokal RR, Rohlf FJ (1995) Biometry, 3rd edn. WH Freeman and $\mathrm{Co}$, New York

Tanaka Y (1984) Morphological and physiological characteristics of the post larval stages in Corbicula japonica Prime, reared in the laboratory. Bull Natl Res Inst Aquaculture 6: 23-27 (in Japanese)

Tango T, Yamaoka K. Takagi $H$ (1996) Logistic regression analysis. Asakura Shoten, Tokyo (in Japanese)

Submitted: May 20, 1998; Accepted: December 12, 1998

Proofs received from author(s): April 12, 1999 